PRADIP NINAN THOMAS is COdirector of the Centre for Communication and Social Change at the University of Queensland, Australia.

\section{Opportunities, tensions in} participatory journalism

Participatory Journalism: Guarding open gates at online newspapers, edited by Jane Singer, Alfred Hermida, David Domingo, Ari Heinonen, Steve Paulussen, Thorsten Quandt, Zvi Reich, and Marina Vujnovic. Oxford: Wiley-Blackwell, 2011, 240 pp. ISBN: 9781444332278 (pbk).

$\mathrm{T}$ HE TITLE of this book reflects the anxiety facing 'professional' journalists and 'mainstream' journalism today as a variety of personal and networking technologies facilitate the expansion of 'produsage' as an ethic and practice, and as the means and end of journalism. This book explores that key questionwhen people formerly known as the 'audience' engage in the making of journalism, what does this mean to the practice and the practitioners of 'professional' journalism?

Based on interviews with a range of newspaper professionals involved
Jane B. Singer, Alfred Hermida, David Domingo, Ari Heinonen,

Steve Paulussen, Thorsten Quandt, Zvi Reich, Marina Vujnovic

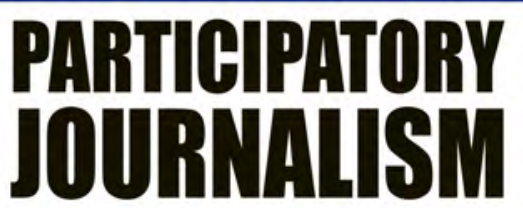

Guarding Open Gates at Online Newspapers

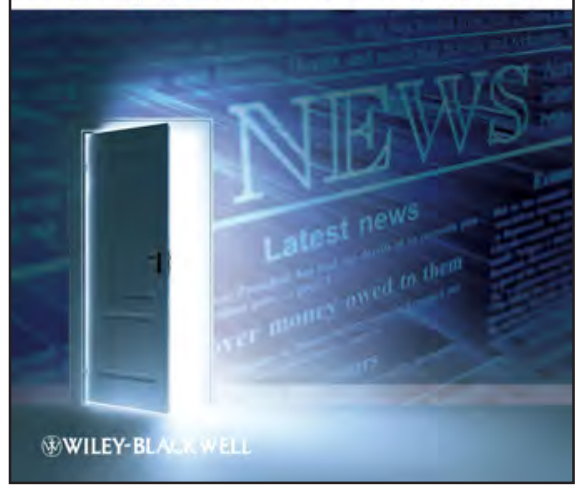

in online news production in 10 Western democracies, including Standard.be (Belgium) Le Figaro.fr and LeMonde.fr/LePost.fr (France), ElPais.com and 20 Minutos.es (Spain), Guardian.co.uk and Telegraph.co.uk (UK) and USAToday.com and WashingtonPost.com (USA), it explores the opportunities and tensions involved in the making of participatory journalism, the persistence of witting and unwitting bias in the making of online news that tends to favour the input of 'professional' journalists, the spaces available for the making of participatory journalism, journalists perceptions of participatory journalism, the management of legal and 
ethical issues related to viewer comments, the economics of participatory journalism, the value of participatory journalism and the valuation of participatory journalists and their input, and the growing significance of participatory journalism.

As one of the first studies on the integration of participation in the making of online news, this volume offers a textured account of the whys and hows of participation from the perspective of the newspaper industry thus providing a valuable counterpoint to the many studies on citizen journalism as either an independent activity or linked to the practice of citizen journalism. The study clearly reveals that online newspapers now offer a variety of options for participation, from citizen blogs, to comments, citizens stories and involvement in forums, although this embrace of participation remains for the most part, a tactical option that corresponds with an appreciation of the mood of the times, rather than an ethic grounded in the implicit appreciation of popular contributions to mainstream journalism.

In other words, while online news editors are now open to citizens contributing 'hyperlocal' news, and news on the weather, lifestyle, travel, in text and image, via blogs and other tools, for the most part, this news is corralled into sections that are clearly demarcated from the news produced by professional journalists. So the making of hard news online remains, for the most part, in the ambit of professional journalists.

To some extent, the key finding related to the ambivalence of online journalism to participatory journalism was to be expected. While the openness of participatory journalism makes sense from a citizen's perspective - the tag line - 'anyone can be a journalist' adopted by the highly successful South Korean citizen journalist venture OhMyNews, is provocative since it really does throw the gauntlet to professional journalists since it questions one of mainstream journalism's central myths - the 'professional' journalist. So it is unsurprising that online journalists interviewed in the making of this volume were for the most part, ambivalent about the prospects for 'real' participation in the making of news by those considered non-professionals. Perhaps the authors of this volume were a little too earnest in their expectations of and understanding of 'participation' given that most people are happy if their voice is taken seriously but are certainly not interested in their contributions supplanting the voices of professional journalists.

This is a very useful contribution to the study of participatory journalism. The chapters deal with 
participatory journalism in relation to the practice of online journalism and include an extensive account of how audience participation is being defined, managed and operationalised in online newsrooms and highlights the continuing tensions between minimalist and maximalist understandings of participation in these newsrooms. Alfred Hermida's chapter 2 on the 'Mechanism of Participation' offers a very useful overview of participation and the accompanying information on the methodology used in this study along with the glossary contribute to a tight well-structured, accessible text on the relationship between online newspapers and participatory journalism.

\section{DREADLOCKS: \\ OCEAN, ISLAND AND SKIES SPECIAL EDITION}

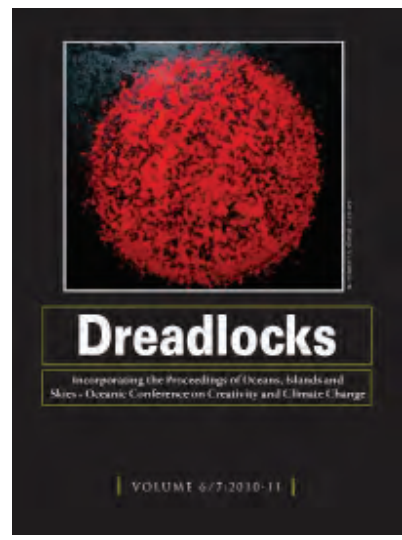

Edited by

\section{Mohit Prasad}

This special edition of the literary journal Dreadlocks incorporates proceedings from Oceans, Islands and Skies - Oceanic Conference on

Creativity and Climate Change. The conference highlighted the role of writers, artists and the media in environmental challenges in the

Pacific. The conference was held from

13-17 September 2010 at the Laucala

Campus of the University of the South Pacific in Suva.

Pacific Studies | Vol 6/7

ISBN 978-1-927184-02-8

MARCH 2012 , RRP: $\$ 35$

Published by: PAcific Writing Forum

AND THE UNIVERSITY OF THE

South Pacific, Suva, Fiji; Pacific

Media Centre (AUTUniversity).

AUCKLAND

PACIFIC MEDIA CENTRE

AUTUNIVERSITY

ORder fRom LitTLE ISLAND PRESS

AND BOOKSHOPS

LITTLEISLAND.CO.NZ
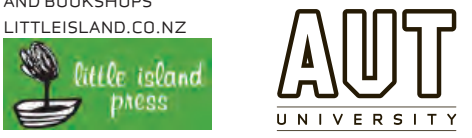